\title{
What happens in the leucotomised brain? A post- mortem morphological study of brains from schizophrenic patients
}

\author{
BENTE PAKKENBERG \\ From the Neurologic Research Laboratory, University Hospital of Hvidovre, Copenhagen, Denmark
}

SUMMARY Volume measurements were carried out on 19 brains from leucotomised schizophrenic patients and 20 age- and sex-matched controls using a stereological method. The volume of the total fixed brain, hemispheres, cortex, white matter, and central grey matter were all significantly reduced compared with controls. White matter and central grey structures were significantly reduced compared with a group of non-leucotomised schizophrenic brains. No difference was found in the size of the lesions in patients who improved compared with the patients who remained unchanged and the outcome was unrelated to lesional asymmetry. Morphometric measurements were correlated to a number of clinical parameters.

Psychosurgery has been performed since the late 19th century' ${ }^{\prime}$ and was inspired by the favourable results of Moniz $^{2}$ with frontal leucotomy having its heyday in the 1940s. The following years prefrontal leucotomy was performed on a great number of patients. Tooth and Newton ${ }^{3}$ have reviewed over 10000 cases who had been operated on in Great Britain in the decade following 1942. Some two-thirds of the patients were schizophrenic and about one-quarter had affective disorders. Of the schizophrenics $18 \%$ showed signs of improvement while as many as $50 \%$ of those with affective disorders improved considerably or recovered. The death rate was $0 \cdot 3 \%$

Critical follow-up investigations in the $1950 \mathrm{~s}^{45}$ described the so-called post-lobotomy syndrome and the active antipsychotic drugs (such as chlorpromazine) were introduced in the treatment of chronic schizophrenia. This caused a large reduction in the number of frontal leucotomies in the following years. Very few follow-ups have been published regarding post-mortem changes in the leucotomised brains, ${ }^{6}$ and modern morphometric methods have not been applied.

It was considered of interest to evaluate the postmortem consequences of destruction of areas in human brains. With a new stereological method it is

Address for reprint requests: Bente Pakkenberg, MD, Neurological Research Laboratory, PAV. 4, University Hospital of Hvidovre, Kettegards Allé 30, 2650 Hvidovre, Denmark.

Received 11 December 1987 and in revised form 15 July 1988. Accepted 21 July 1988 possible to estimate the total volume of the hemispheres, cortex, white matter, central grey structures and ventricles and include the size of the leucotomy lesions. Care was taken to correlate structural changes after leucotomy with clinical parameters.

\section{Material}

From a collection containing 52 brains from patients with chronic schizophrenia 19 brains from schizophrenic patients on whom a leucotomy had been performed were matched by age and sex with 20 control brains obtained from three pathologic departments in Copenhagen. The schizophrenic brains were collected from two psychiatric hospitals of chronic patients over a period of 12 years (1972-1984). The diagnoses were given according to ICD-9 and fulfilled the criteria of DSM-III. ${ }^{7}$ The brains had been removed within 72 hours of death and stored from 1973-85 in 10\% formalin for at least five months to ensure a stable volume. ${ }^{8}$ Exclusion criteria were strokes or tumours in the CNS, and alcohol or drug abuse. Patients with malignant disease (cases No 10,15 and 18) had no direct or indirect involvement of the brain. Patients who had been comatose for more than 24 hours prior to death were also excluded. Furthermore, any record of dementia or death from cancer led to exclusion of control brains. Table I shows diagnosis, age at first admission, number of years as psychiatric in-patients, treatment, and development of dyskinesia (if any); 12 had developed dyskinesia, 11 being oral dyskinesia, and 10 patients had had such additional symptoms as hyperkinesias of the head, body or extremities and/or tremor of the hands. The symptoms had appeared from 3-19 years after the start of treatment. All patients had received high doses of the neuroleptic group of drugs.

Seven patients had seven first-degree and two second- 
Table 1 Details of the patients

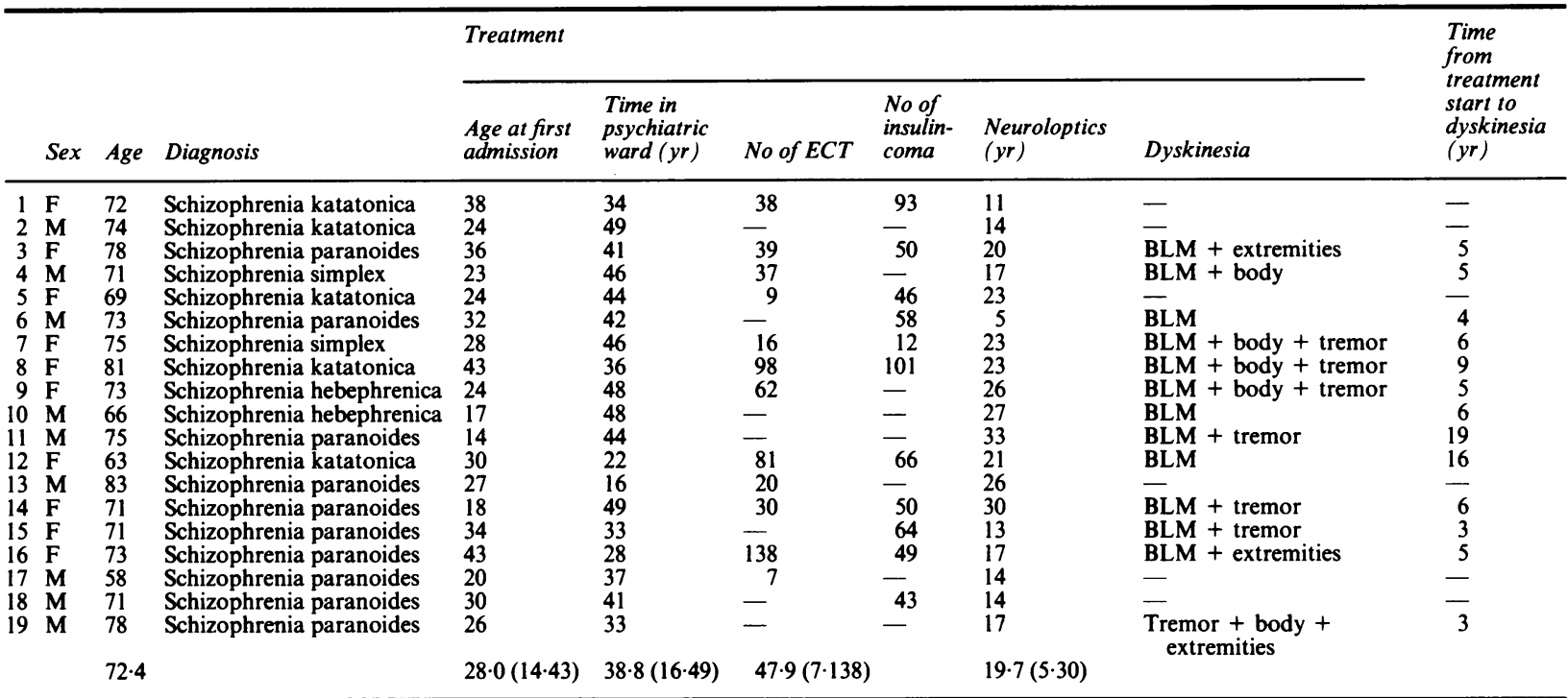

degree relatives who were schizophrenic; three patients had six second-degree relatives with schizophrenia; one patient had an alcoholic father; two patients had manic-depressive uncles; one patient had a son who became mentally disturbed and later committed suicide.

Table 2 shows general information of the patients, the causes of death and factor of first-degree inheritance: The fixation time of the schizophrenic brains is on average six times as long as that of controls which is relatively unimportant, since a stable volume has been established after five months of fixation. ${ }^{8}$

Table 3 gives details of the leucotomies. All patients had undergone bilateral frontal leucotomy; seven had had a re-operation because of decreasing or lack of effect from the first operation, two of the operations included bilateral amygdalotomy. Table 4 shows the general parameters of the controls.

To evaluate the effect of leucotomy on the components of the brain a comparison was made between the 19 schizophrenic leucotomised patients and a group of 26 chronic schizophrenic patients without leucotomy from the original brain collection of 52 brains. These patients (14 males and 12 females) had an average age of 73.3 years, an age at first admission of 32.2 years, had spent an average of 33.2 years in a psychiatric hospital and were treated with neuroleptic drugs for an average of 17 years. Information concerning all data of

Table 2 Height and weight of patients, details of the fixed brains

\begin{tabular}{|c|c|c|c|c|c|c|c|c|}
\hline $\begin{array}{l}\text { Case } \\
\text { No }\end{array}$ & $\begin{array}{l}\text { Height } \\
(\mathrm{cm})\end{array}$ & $\begin{array}{l}\text { Weight } \\
(\mathbf{k g})\end{array}$ & $\begin{array}{l}\text { Total weight } \\
\text { of fix. brain } \\
\text { (g) }\end{array}$ & $\begin{array}{l}\text { Time } \\
\text { death/fix. } \\
\text { ( } 24 \text { hours) }\end{array}$ & $\begin{array}{l}\text { Fix. time } \\
\text { (months) }\end{array}$ & $\begin{array}{l}\text { Time from } \\
\text { terminal illness } \\
\text { to death }\end{array}$ & Cause of death & $\begin{array}{l}\text { Factor of } \\
\text { inheritance }\end{array}$ \\
\hline $\begin{array}{r}1 \\
2 \\
3 \\
4 \\
5 \\
6 \\
7 \\
8 \\
9 \\
10 \\
11 \\
12 \\
13 \\
14 \\
15 \\
16 \\
17 \\
18 \\
19\end{array}$ & $\begin{array}{l}164 \\
166 \\
162 \\
175 \\
163 \\
169 \\
162 \\
161 \\
171 \\
165 \\
165 \\
169 \\
175 \\
163 \\
155 \\
159 \\
171 \\
163 \\
190 \\
166 \cdot 7 \\
(155-190)\end{array}$ & $\begin{array}{l}48 \cdot 3 \\
72 \cdot 5 \\
44 \cdot 4 \\
83 \cdot 0 \\
49 \cdot 0 \\
82 \cdot 4 \\
60 \cdot 8 \\
53 \cdot 0 \\
41 \cdot 5 \\
79 \cdot 2 \\
42 \cdot 5 \\
54 \cdot 9 \\
70 \cdot 5 \\
59 \cdot 4 \\
60 \cdot 5 \\
51 \cdot 1 \\
98 \cdot 8 \\
72 \cdot 5 \\
75 \cdot 0 \\
63 \cdot 1 \\
(41 \cdot 5-98 \cdot 8)\end{array}$ & $\begin{array}{r}1060 \\
1010 \\
1100 \\
1280 \\
990 \\
1220 \\
1080 \\
1090 \\
1130 \\
1135 \\
1144 \\
1335 \\
1190 \\
1305 \\
970 \\
940 \\
1090 \\
1116 \\
1416 \\
1137 \\
(940-1416)\end{array}$ & $\begin{array}{l}1 \\
2 \\
2 \\
2 \\
2 \\
2 \\
3 \\
3 \\
2 \\
3 \\
3 \\
3 \\
2 \\
3 \\
1 \\
2 \\
2 \\
2 \\
1 \\
1 \\
2 \\
2\end{array}$ & $\begin{array}{l}118 \\
120 \\
108 \\
75 \\
72 \\
57 \\
46 \\
26 \\
60 \\
20 \\
5 \\
72 \\
11 \\
9 \\
168 \\
168 \\
70 \\
146 \\
50 \\
73 \cdot 8 \\
(5-168)\end{array}$ & $\begin{array}{l}\text { Days } \\
\text { Hours } \\
\text { Days } \\
\text { Hours } \\
\text { Days } \\
\text { Days } \\
\text { Hours } \\
\text { Min } \\
\text { Days } \\
\text { Months } \\
\text { Months } \\
\text { Days } \\
\text { Days } \\
\text { Min } \\
\text { Months } \\
\text { Days } \\
\text { Min } \\
\text { Months } \\
\text { Min }\end{array}$ & $\begin{array}{l}\text { Bronchopneumonia } \\
\text { Coronary occlusion } \\
\text { Bronchopneumonia } \\
\text { Cardiac failure } \\
\text { Bronchopneumonia } \\
\text { Bronchopneumonia } \\
\text { Cardiac failure } \\
\text { Pulmonary embolism } \\
\text { Bronchopneumonia } \\
\text { Cancer of the bladder } \\
\text { Chronic bronchitis } \\
\text { Bronchopneumonia } \\
\text { Bronchopneumonia } \\
\text { Coronary occlusion } \\
\text { Ovaric cancer } \\
\text { Bronchopneumonia } \\
\text { Pulmonary embolism } \\
\text { Hodgkin's disease } \\
\text { Pulmonary embolism }\end{array}$ & $\begin{array}{l}\times \\
\times \\
\times \\
\times \\
\times \\
\times\end{array}$ \\
\hline
\end{tabular}


Table 3 Details of the leucotomies

\begin{tabular}{|c|c|c|c|c|c|c|c|c|c|c|}
\hline $\begin{array}{l}\text { Case } \\
\text { No }\end{array}$ & $\begin{array}{l}\text { Age at } \\
\text { leucotomy }\end{array}$ & $\begin{array}{l}\text { Time from } \\
\text { leucotomy } \\
\text { to death } \\
(y r)\end{array}$ & $\begin{array}{l}\text { Bilateral } \\
\text { basofrontal } \\
\text { leucotomy }\end{array}$ & Relob & $\begin{array}{l}\text { Volume of } \\
\text { defect } \\
\text { (\% of brain) }\end{array}$ & $\begin{array}{l}\text { Size of } \\
\text { lesion }(\mathrm{ml}) \\
\text { left lobus } \\
\text { frontalis }\end{array}$ & $\begin{array}{l}\text { Size of } \\
\text { lesion ( } \mathrm{ml}) \\
\text { right lobus } \\
\text { frontalis }\end{array}$ & Effect & Epilepsy & $\begin{array}{r}\overline{\bar{D}} \\
\text { Dement } \\
\text { autistik }\end{array}$ \\
\hline $\begin{array}{l}1 \\
2 \\
3 \\
4 \\
5 \\
6 \\
7 \\
8\end{array}$ & $\begin{array}{l}47 \\
53 \\
48 \\
41 \\
58 \\
40 \\
50 \\
48\end{array}$ & $\begin{array}{l}25 \\
21 \\
30 \\
30 \\
11 \\
33 \\
25 \\
33\end{array}$ & $\begin{array}{l}+ \\
+ \\
+ \\
+ \\
+ \\
+ \\
+ \\
+ \\
+ \text { Amygdalotomi }\end{array}$ & $\begin{array}{l}+ \\
\dot{-} \\
+ \\
- \\
- \\
++\end{array}$ & $\begin{array}{l}3.89 \\
4.08 \\
1.51 \\
7.47 \\
5.44 \\
0.56 \\
7.62 \\
6.86\end{array}$ & $\begin{array}{r}16.8 \\
15 \cdot 7 \\
5.8 \\
42 \cdot 6 \\
22.7 \\
0.6 \\
32.7 \\
32.9\end{array}$ & $\begin{array}{r}16 \cdot 8 \\
15 \cdot 7 \\
6 \cdot 8 \\
44.8 \\
20.5 \\
3.5 \\
35.1 \\
31 \cdot 2\end{array}$ & $\begin{array}{l}\mathbf{I} \\
\mathbf{A} \\
\mathbf{I} \\
\mathbf{U} \\
\mathbf{U} \\
\mathbf{I} \\
\mathbf{W} \\
\mathbf{I}\end{array}$ & $\begin{array}{l}+ \\
+ \\
+ \\
+ \\
+ \\
+ \\
+\end{array}$ & 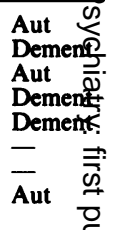 \\
\hline $\begin{array}{l}9 \\
10 \\
11 \\
12 \\
13 \\
14 \\
15 \\
16 \\
17 \\
18 \\
19\end{array}$ & $\begin{array}{l}40 \\
33 \\
44 \\
39 \\
53 \\
37 \\
47 \\
52 \\
29 \\
49 \\
47 \\
45.0 \\
(29-58)\end{array}$ & $\begin{array}{l}33 \\
33 \\
31 \\
24 \\
30 \\
34 \\
24 \\
21 \\
29 \\
22 \\
31 \\
27 \cdot 4 \\
(11-34)\end{array}$ & $\begin{array}{l}+ \\
+ \\
+ \\
+ \\
+ \\
+ \\
+ \\
++ \\
+ \\
+ \\
+\end{array}$ & $\begin{array}{l} \pm \\
- \\
- \\
- \\
- \\
+ \\
\pm \\
- \\
+\end{array}$ & $\begin{array}{l}1.78 \\
2.21 \\
5.60 \\
0.93 \\
1.46 \\
1.13 \\
6.01 \\
1.65 \\
0.64 \\
2.67 \\
2.88\end{array}$ & $\begin{array}{r}8.2 \\
9.8 \\
20.2 \\
1 \cdot 7 \\
6 \cdot 7 \\
5 \cdot 7 \\
20 \cdot 1 \\
8 \cdot 5 \\
3 \cdot 1 \\
8 \cdot 8 \\
11.8\end{array}$ & $\begin{array}{r}7.9 \\
7.8 \\
30.6 \\
8.5 \\
7.8 \\
5.9 \\
25 \cdot 2 \\
4.6 \\
2.5 \\
13.4 \\
20.3\end{array}$ & $\begin{array}{l}\text { U } \\
\mathbf{I} \\
\mathbf{I} \\
\mathbf{U} \\
\mathbf{U} \\
\mathbf{U} \\
\mathbf{U} \\
\mathbf{U} \\
\mathbf{U} \\
\mathbf{A} \\
\mathbf{A}\end{array}$ & $\begin{array}{l}\overline{-} \\
\overline{-} \\
\overline{-} \\
\overline{-} \\
\overline{-} \\
\overline{+} \\
+\end{array}$ & 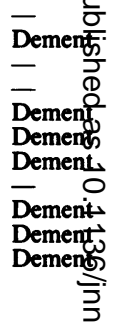 \\
\hline
\end{tabular}

$I=$ improved, $\mathbf{A}=$ ambiguous, $\mathrm{U}=$ unchanged, $\mathbf{W}=$ worse.

the group of 26 schizophrenic patients has been published elsewhere.' The leucotomies were performed between 1944 and 1954 using bilateral frontal leucotomy with medial undercutting of Brodman areas 9, 10-and half of Brodman 11 , during the 1940 s and early 1950 s; these operations were the standard frontal leucotomy. Later more precise lesions were induced by electrocoagulation, aimed at the ventromedial quandrant of the frontal lobe. In order to find possible differences between patients with post-operative improvement $(n=6)$ and those who had remained unchanged $(n=9)$ the classification of Meyer and Beck $^{6}$ was applied. The coronal sections through the frontal lobe were divided into anterior (A), middle (M) and posterior $(\mathrm{P})$. Each section was divided into seven segments and used for plotting the lesions in each case, see fig. The thalamo-prefrontal projection passes through the mid-central segment. The sizes of the lesions were estimated separately for the left and right lobes to evaluate the effect of asymmetric lesions in the frontal lobe. Operational results were based solely on the patients' case records at 6-24 months after operation, and included no psychological tests. In case of re-operation, the results are expressed as the final outcome of both operations.

Results were classified as improvement, unchanged, worse and ambiguous. Results were classified ambiguous when

Table 4 Details of controls

\begin{tabular}{|c|c|c|c|c|c|c|c|c|c|}
\hline & Sex & Age & $\begin{array}{l}\text { Height } \\
(\mathrm{cm})\end{array}$ & $\begin{array}{l}\text { Weight } \\
(\mathrm{kg})\end{array}$ & $\begin{array}{l}\text { Total weight } \\
\text { of fix brain } \\
(\mathrm{g})\end{array}$ & $\begin{array}{l}\text { Time } \\
\text { death/fix } \\
\text { (24 hours) }\end{array}$ & $\begin{array}{l}\text { Fix time } \\
\text { (months) }\end{array}$ & $\begin{array}{l}\text { Time from } \\
\text { terminal illness } \\
\text { to death }\end{array}$ & Cause of death \\
\hline $\begin{array}{r}1 \\
2 \\
3 \\
4 \\
5 \\
6 \\
7 \\
8 \\
9 \\
10 \\
11 \\
12 \\
13 \\
14 \\
15 \\
16 \\
17 \\
18 \\
19 \\
20\end{array}$ & $\begin{array}{l}\mathbf{M} \\
\mathbf{M} \\
\mathbf{M} \\
\mathbf{F} \\
\mathbf{M} \\
\mathbf{F} \\
\mathbf{F} \\
\mathbf{F} \\
\mathbf{F} \\
\mathbf{M} \\
\mathbf{F} \\
\mathbf{F} \\
\mathbf{M} \\
\mathbf{F} \\
\mathbf{M} \\
\mathbf{M} \\
\mathbf{F} \\
\mathbf{F} \\
\mathbf{M} \\
\mathbf{M}\end{array}$ & $\begin{array}{l}82 \\
75 \\
84 \\
88 \\
73 \\
60 \\
86 \\
84 \\
75 \\
71 \\
69 \\
67 \\
74 \\
57 \\
59 \\
57 \\
65 \\
75 \\
72 \\
84 \\
72 \cdot 9 \\
(57-88)\end{array}$ & $\begin{array}{l}177 \\
182 \\
158 \\
165 \\
171 \\
162 \\
166 \\
160 \\
166 \\
175 \\
162 \\
167 \\
170 \\
162 \\
179 \\
174 \\
159 \\
158 \\
163 \\
170 \\
167 \cdot 3 \\
(158-182)\end{array}$ & $\begin{array}{l}56 \cdot 0 \\
73 \cdot 0 \\
51 \cdot 0 \\
47 \cdot 7 \\
73 \cdot 0 \\
50 \cdot 0 \\
44 \cdot 0 \\
53 \cdot 0 \\
84 \cdot 7 \\
72 \cdot 0 \\
81 \cdot 8 \\
62 \cdot 0 \\
74 \cdot 0 \\
50 \cdot 0 \\
70 \cdot 0 \\
80 \cdot 0 \\
61 \cdot 0 \\
48 \cdot 0 \\
70 \cdot 2 \\
80 \cdot 8 \\
64 \cdot 1 \\
(44 \cdot 0-84 \cdot 7)\end{array}$ & $\begin{array}{l}1129 \\
1360 \\
1230 \\
1310 \\
1270 \\
1360 \\
1133 \\
1253 \\
1270 \\
1355 \\
1125 \\
1205 \\
1320 \\
1360 \\
1450 \\
1550 \\
1450 \\
1175 \\
1175 \\
1400 \\
1294 \\
(1125-1550)\end{array}$ & $\begin{array}{l}2 \\
1 \\
1 \\
2 \\
3 \\
1 \\
2 \\
2 \\
1 \\
1 \\
3 \\
1 \\
3 \\
1 \\
2 \\
1 \\
1 \\
1 \\
2 \\
1\end{array}$ & $\begin{array}{r}5 \\
7 \\
5 \\
9 \\
96 \\
6 \\
5 \\
5 \\
11 \\
11 \\
11 \\
11 \\
11 \\
6 \\
6 \\
6 \\
5 \\
5 \\
10 \\
9 \\
12 \\
(5-96)\end{array}$ & $\begin{array}{l}\text { Hours } \\
\text { Min } \\
\text { Hours } \\
\text { Min } \\
\text { Hours } \\
\text { Days } \\
\text { Hours } \\
\text { Months } \\
\text { Min } \\
\text { Days } \\
\text { Days } \\
\text { Min } \\
\text { Days } \\
\text { Min } \\
\text { Days } \\
\text { Min } \\
\text { Hours } \\
\text { Min } \\
\text { Min } \\
\text { Days }\end{array}$ & $\begin{array}{l}\text { Cardiac failure } \\
\text { Coronary occlusion } \\
\text { Coronary occlusion } \\
\text { Coronary occlusion } \\
\text { Coronary occlusion } \\
\text { Coronary occlusion } \\
\text { Coronary occlusion } \\
\text { Coronary occlusion } \\
\text { Coronary occlusion } \\
\text { Cardiac failure } \\
\text { Bronchopneumonia } \\
\text { Pulmonary embolism } \\
\text { Mesenteric thrombosis } \\
\text { Coronary occlusion } \\
\text { Coronary occlusion } \\
\text { Coronary occlusion } \\
\text { Coronary occlusion } \\
\text { Coronary occlusion } \\
\text { Coronary occlusion } \\
\text { Septic shock }\end{array}$ \\
\hline
\end{tabular}



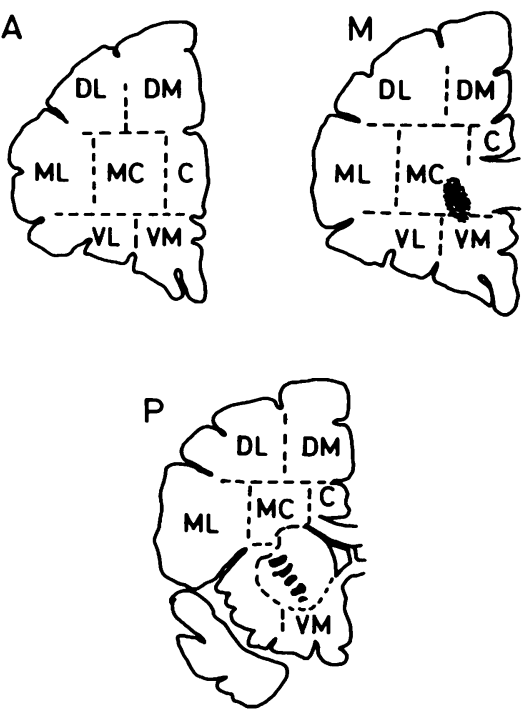

Fig The frontal lobe shown divided into anterior $(A)$, middle $(M)$ and posterior $(P)$ planes. Each section is divided into seven segments termed: $D M=$ dorso-medial; $D L=$ dorso-lateral; $M L=$ mid-lateral; $V L=$ ventro-lateral,$V M=$ ventro-medial $; M C=$ mid-central segment; and $C=$ cingulate.

improvement of schizophrenic symptoms was accompanied by serious side-effects, such as development of "frontal lobe syndrome", characterised by euphoria, lack of judgment and emotional flatness. In cases of doubt between improvement and ambiguous, the effect was described as improvement, since improvement was the dominant feature in all these cases.

\section{Method}

The brains were weighed, the meninges removed and the cerebellum and the brain stem cut off corresponding to the upper level of the pons. The brains were incubated in gelatin, cut in coronal slices $6 \mathrm{~mm}$ thick, and photographed. Colour slides were then produced and the slides point-counted using a double-lattice grid with 64 coarse points and 1024 fine points. The length of the brain was measured minus the first and the last slice and the average thickness of the brain slices calculated. The volumes of the hemispheres, cortex, white matter, ventricles, central grey matter and lesions caused by the leucotomy were estimated using Cavaliri's theorem, ${ }^{10}$ the simplest and generally most informative measure of three dimensional volume accessible on parallel sections:

Volume $=\mathbf{t} \times \mathrm{a}_{\mathrm{p}} \times \mathbf{\Sigma} \mathbf{P}$

$\mathrm{t}=$ length of brain - (first and last slice)/number of slices

$-2$

$a_{p}=$ area per point of the grid, corrected for magnification.

$\Sigma P=$ the total number of points that falls on the object presently counted

The coefficient of error $\mathrm{CE}=\mathbf{0 . 0 2 8}$.
$\mathrm{CV}=\mathrm{SD} /$ mean, a dimensionless quantity reporting the relative interindividual variation within a group.

\section{Statistical method}

A positive correlation exists between body height and brain weight in homo sapiens. ${ }^{112}$ For this reason the volumes of the brain, the hemispheres, the cortex, white matter and ventricles were correlated to body height. Two regression-lines were always compared, either a test group to a control group or a test group to a test group. The difference in the level of regression-lines is considered statistically significant for $2 p$ less than 0.05 . In the control group only the slope of the regression-line for central grey matter was found to be significantly different from 0 , probably due to the small number of individuals in the sample.

\section{Results}

A statistically significant difference was found between the weight of the total, fixed brain from the control group $\left(\mathrm{X}_{\text {control }}=1294 \mathrm{~g}\right)$ and the schizophrenic leucotomised group $\left(X_{\text {levcotomy }}=1137 \mathrm{~g}\right), 2 \mathrm{p}=$ 0.000004 . The volume of the cortex, white matter, central grey structures and ventricles, the $\mathrm{CV}$ and the $2 p$ values for controls, leucotomised schizophrenic and schizophrenic brains without leucotomy are shown in table 5 . The ventricular volume from the $\mathbf{1 0}$ demented patients did not differ significantly from those of the other leucotomised brains $(2 p=0 \cdot 15)$. The 13 patients who had developed hyperkinesia had a significant difference in the volume of central grey matter $(2 p=0.007)$ while no difference was found in the ventricular volume $(2 p=0.43)$ compared with those of the remainder of the leucotomised group. There was no significant difference in the length of neuroleptic treatment in the patients who had developed dyskinesia compared with the remainder of the leucotomised patients $(2 p=0 \cdot 19)$.

The cortical volume from the 12 patients who had undergone ECT treatment showed no significant difference from those of the other leucotomised schizophrenics $(2 p=0 \cdot 10)$. Eight patients had developed epilepsy after (mean $=7.9 \mathrm{y}$, range: $1-23$ ) the operation, probably due to the leucotomy; all patients had generalised seizures. The epileptics had significantly larger lesions (mean lesion volume $=5.11 \%$ of hemisphere volume) compared with the rest of the leucotomised schizophrenic patients (mean lesion volume $=2 \cdot 13 \%$ of hemisphere volume) $2 p=0.003$.

There was no significant difference between epileptics and the other leucotomised schizophrenics in their cortex and white matter volumes $(2 p=0 \cdot 24)$.

To ascertain whether the result of the operation was related to the size of the post-operative lesion in the frontal lobe, the six patients who improved were compared with the nine patients who were unchanged. The percentage size of the lesions in the improved 
Table 5 Data of control and patient brains

\begin{tabular}{|c|c|c|c|c|}
\hline & Cortex & White matter & Central grey structures & Ventricles \\
\hline $\begin{array}{l}\text { Controls } \\
\text { Leucotomised schizophrenics } \\
\text { Non-leucostomised schizophrenics }\end{array}$ & $\begin{array}{l}561 \quad(0,13) \\
482 \ddagger \\
510 \text { NS }(0,16)\end{array}$ & $\begin{array}{l}390(0,14) \\
316 \pm(0,16) \\
370^{*}(0,23)\end{array}$ & $\begin{array}{l}47,5(0,13) \\
38,9 \ddagger(0,19) \\
44,5^{*}(0,16)\end{array}$ & $\begin{array}{l}25,9(0,32) \\
30,6 \text { NS }(0,52) \\
35,1 \text { NS }(0,48)\end{array}$ \\
\hline
\end{tabular}

NS, non-significant; ${ }^{*} 2 p<0.05 ; \nmid 2 p<0.01 ; \ddagger 2 p<0.001$.

Figures in brackets is $\mathrm{CV}=\mathrm{SD} /$ mean.

patients $(3 \cdot 44 \%)$ did not differ significantly from the percentage size of the lesions in the unchanged patients $(2.95 \%) 2 p=0.46$.

Although no significant difference was found in the size of the total lesions between improved and unchanged patients, a difference was found between the number of segments affected and their localisation in the frontal lobe. In the improved patients the segments from which most of white matter was lost after leucotomy were in the middle plane, MC being affected in all cases, DL in $83 \%$ and DM in $50 \%$. Fifty four per cent of the total number of affected segments were located to the middle plane. In the anterior plane, MC was affected in $66 \%, \mathrm{DM}$ in $33 \%$ and $\mathrm{C}$ in none. Thirty two per cent of the total number of affected segments were located to the anterior plane. The remaining $14 \%$ of affected segements were located in the posterior plane.

In the unchanged patients the largest number of affected segments was in the anterior plane, where $54 \%$ of the affected segments were located, MC being affected in $89 \%$ of the cases, DM in $56 \%$ and $C$ in $33 \%$. In the middle plane MC was affected in $67 \%$ of the cases, DL in $33 \%$ and DM in $22 \%$. Thirty eight per cent of the affected segments were located to the middle plane. The remaining $8 \%$ of affected segments were located to the posterior plane.

To test whether the outcome of the operation was related to lesional asymmetry, the difference in volume of the lesions of the right and left lobes was compared in the six patients who had improved (mean$=3.00 \mathrm{ml}$ ) and the nine patients who had remained unchanged (mean $=2.49 \mathrm{ml}$ ). The difference was not significant, $2 \mathrm{p}=0.44$.

\section{Discussion}

A statistically significant difference was found between the volume of the hemispheres in the leucotomised patients compared with those in the control group. The stereological method used in the present study ensures that the volume of the lesions left by leucotomy are included in the volume of the hemispheres so the difference represents a "true" loss of substance. This decreased volume is due to a general reduction of all parameters, for example, cortex, white matter and central grey structures of which white matter and central grey structures were statistically significant. The significant difference of white matter is due to leucotomy, the pronounced difference in central grey structures the more interesting, indicating that leucotomy also affects central areas of the brain. No correlation was found between the volume of the lesion and the loss of volume of central grey matter. Thus frontal leucotomy is associated with loss of substance in areas innervated by prefrontal cortex, but unrelated to the volume of the lesions.

Although prefrontal leucotomy for schizophrenic patients is now obsolete, stereotactic psychoneurosurgery is not. It is impossible to do justice to the numerous workers who have contributed the anatomical and experimental facts on which our present knowledge of the interrelations between the human cortex and central grey structures has been established. ${ }^{613}$ Our current knowledge about the function of the frontal lobe is partly derived from the results of this pioneering work. Thus in 1951 Fulton $^{13}$ was able to recommend the anterior cingulate and the medial orbital cortex as the optimal targets for neurosurgery in the frontal region: the cingular region to counter aggression and hyperactivity and the? orbital segment to combat depression and subnormal psychomotor activity in schizophrenia.

Naeser et al.$^{14}$ performing computed tomography of 17 schizophrenic men who had undergone bilateral prefrontal leucotomy 25 years earlier found that the cases with good recovery $(n=6)$ and significantly larger lesions in the low orbito-frontal region (especially on the left side) than those cases with only moderate or no recovery. In the present study no difference was found in the size of the lesions in patients who improved compared to the patients who remained unchanged. The location of leucotomy seemed to be more important than the size of the lesion (table 3). Possibly this observation which is not in accordance with Naeser et $a l^{14}$ or Meyer and Beck could be due to the fact that in the present study the total volume of the leucotomy lesions was determined. It is noteworthy that the mid-central segment was affected in the middle plane of all the cases who improved. In contrast to the findings of Naeser et al ${ }^{14}$ the effect of leucotomy was found to be unrelated to lesional asymmetry.

No statistically significant difference was found in 
the volumes of the ventricles in the leucotomised patients and the control group. This is surprising since leucotomy is normally associated with increased ventricular size and in some cases with distortion of the ventricles. ${ }^{15}$

In this study the normal volume of the ventricles in leucotomised schizophrenic groups is surprising, since schizophrenics often have enlarged ventricles. ${ }^{915-18}$ Possibly this lack of size difference may be due to the rather high age of the patients. It has been shown in previous studies ${ }^{919}$ that the normal positive correlation between ventricular size and age does not occur in schizophrenics. The age-related enlargement of the ventricular system may be obscured in some way in such patients. This might explain why this group of patients with an average age of $72 \cdot 4$ years did not have the expected ventricular enlargement, which most likely would have been present had the patients been examined at a younger age. The ventricles of the demented patients were not enlarged compared with the rest of the leucotomised patients, even though dementia is often associated with central atrophy.

In the present study $65 \%$ of the patients developed hyperkinesia, independent of the length of treatment. It has been a matter of discussion whether leucotomy predisposes to tardive dyskinesia. Hunter et al ${ }^{20}$ described abnormal movements and dementia in leucotomised patients treated with phenothiazines although this was not confirmed by other authors. In a study of 67 leucotomised and 60 non-leucotomised schizophrenics, Faurbye et al ${ }^{21}$ found that $43 \%$ of the leucotomised patients developed tardive dyskinesia compared with $45 \%$ of the non-leucotomised.

In a study including 38 leucotomised patients Brandon et al $^{22}$ found that eight manifested the BLM triad. From the present investigation it seems that leucotomy could be a pathogenic factor in hyperkinesia.

The introduction of chlorpromazine in the early 1950 s revolutionised the treatment of schizophrenia. Most patients in the present study greatly improved their condition when treated with neuroleptics. Although these drugs have many unwanted side-effects, they do much more for the schizophrenic patients than leucotomy. The loss of central brain substance in the leucotomised brains was more pronounced than the one seen in otherwise identical chronic, schizophrenic patients without leucotomy. The loss of central brain tissue thus appeared in structures not primarily affected by leucotomy (white matter) and suggests that stereotactic surgery and other operations such as resection of the temporal lobe in epilepsy, carried out today may increase the risk of inducing morphological changes in the brain besides the ones intended by the intervention.

The author wishes to thank Dr Ulla Noring, Sct Hans
Hospital, for expert help on the schizophrenic cases.

\section{References}

1 Burckhard G. Ueber Rindenexcisionen als Beitrag zur operativen Therapie der Psychosen. Allgemeine Zeitschrift für Psychiatrie 1891;47:463-548.

2 Moniz E. Prefrontal leucotomy in the treatment of mental disorders. Am J Psychiatry 1937;93:1379-85.

3 Tooth GC, Newton MP. Leucotomy in England and Wales 1942-54. Reports on Public Health and Medical Subjects No 104, 1961. Ministry of Health, London: HMSO.

4 Petrie A. Personality and the frontal lobe, 1952. London: Routledge, Kegan Paul.

5 Greenblatt M, Solomon HC. Frontal lobes and schizophrenia. New York: Springer, 1953.

6 Meyer A, Beck E. Prefrontal leucotomy and related operations: anatomical aspects of success and failure (Pub for the William Ramsey Henderson Trust by Oliver and Boyd, Edinburgh), 1954.

7 Bech P, Eplov L, Haaber A, et al. DSM-III, 1988 (in press). (Danish version) translated from: American Psychiatric Association: Quick Reference to the Diagnostic Criteria from Diagnostic and Statistical Manual of Mental Disorders, Third Ed. Washington, DC: APA, 1980, with permission from The Cambridge University Press LTD.

8 Haug H, Kühl S, Mecke E, Sass NL, Wasner K. The significance of morphometric procedures in the investigation of age changes in cytoarchitectonic structures of human brain. J Hirnforsch 1984;25:356-74.

9 Pakkenberg B. Postmortem study of chronic schizophrenic brains. Br J Psychiatry 1987;151:744-52.

10 Cavalieri B. Geometria degli Indivisibili, 1966. Torino: Unione Tipografico-Editrice.

11 Pakkenberg H, Voigt J. Brain weight of the Danes. Acta Anat 1964;56:297-307.

12 Skullerud K. Variations in the size of the human brain. Acta Neurol Scand 1985;Suppl 102, Vol 71.

13 Fulton JF. Frontal Lobotomy and Affective Behaviour: Neurophysiological Analysis, 1951. New York: Norton \& Co.

14 Naeser MA, Levine HL, Benson DF, Stuss DT, Weir WS. Frontal leucotomy size and hemispheric asymmetries on CT scans of schizophrenics with variable recovery. Arch Neurol 1981;38: 30-37.

15 Johnstone EC, Frith CD, Crow TJ, Husband J, Kreel L. Cerebral ventricular size and cognitive impairment in chronic schizophrenia. Lancet 1976;ii:924-6.

16 Andreasen NC, Olsen SA, Dennert JW, Smith MR. Ventricular enlargement in schizophrenia: relationship to positive and negative symptoms. Am J Psychiatry 1982;139:297-302.

17 Nasrallah HA, Jacoby CG, McCalley-Whitters M, Kuperman S. Cerebral ventricular enlargement in subtypes of chronic schizophrenia. Arch Gen Psychiatry 1982;39:774-7.

18 Weinberger DR, DeLisi LE, Perman GP, Targum S, Wyatt RJ. Computed tomography in schizophreniform disorder and other acute psychiatric disorders. Arch Gen Psychiatry 1982;39: 778-83.

19 Nybäck H, Wiesel F-A, Berggren B-M, Hindmarsh T. Computed tomography of the brain in patients with acute psychosis and in healthy volunteers. Acta Psychiatr Scand 1982;65:403-14.

20 Hunter R, Earl CJ, Janz D. A syndrome of abnormal movements and dementia in leucotomised patients treated with phenothiazines. J Neurol Neurosurg Psychiatry 1964;27:219-23.

21 Faurbye A, Rasch P-J, Petersen PB, Brandborg G, Pakkenberg H Neurological symptoms in pharmacotherapy of psychoses. Acta Psychiatr Scand 1964;40:10-27.

22 Brandon S, McClelland HA, Protheroe C. A study of facial dyskinesia in a mental hospital population. Br J Psychiatry 1971;118:171-84. 